\section{UMJETNIK KAO JURODIVI: SVETAC ILI LUEAK?}

DINA POKRAJAC

Palmotićeva 50,

HR - 10000 Zagreb, Hrvatska

dinapokrajac@yahoo.com

orcid.org/0000-0001-6072-1270
DOI: $10.17234 /$ SEC.31.4

Izvorni znanstveni rad

Primljeno: 16. 6. 2019.

Prihvaćeno: 17. 9. 2019.

Ovaj rad nalazi se u otvorenom pristupu i može se distribuirati u skladu s odredbama licencije CC BY-NC-ND 4.0 HR

Ovaj se esej bavi fenomenom svetih luda (jurodivi) u kulturnoj povijesti Rusije kako se dade iščitati u različitim tekstovima - svetim, medicinskim, no primarno umjetničkim (književnost i film). Ruski umjetnici i intelektualci često su mistično angažirani, za njih je sveto transcendentna ontološka stvarnost s kojom se može eksperimentirati. Autorica problematizira način na koji fenomen jurodivih, karakterističan za rusku narodnu kulturu, u jednom zanimljivom povijesnom trenutku postaje isprepleten s mišlju ruskih intelektualaca poput Dostojevskog, Berdjajeva i Tarkovskog, dajući formu za religioznu koncepciju umjetnosti i specifično viđenje položaja umjetnika kao jurodivog "koji se danju ruga svijetu, da bi ga noću oplakivao" i umjetničkih djela kao "putokaza k drugom svijetu".

Ključne riječi: Andrej Tarkovski, Fjodor M. Dostojevski, Aleksandr Sokurov, Nikolaj Berdjajev, antropologija, sveta luda, ruska ideja, heterodoksija, jurodivi

"Spašava samo duh, koji izgrađuje svoje nove forme."

(Nikolaj Berdjajev 1991:74)

"Apsolut je dokučiv samo kroz vjeru i stvaralački čin."

(Andrej Tarkovski 1999)

"Nikakva socijalna i politička ideologija ne dolazi do istinskog sadržaja, ako ga ne pronađe u duhovnom životu, u podloženju svih socijalnih i političkih formi duhovnom cilju."

(Nikolaj Berdjajev 1991:97) 
Ovaj esej bavi se fenomenom svetih luda u kulturnoj povijesti Rusije kako se dade iščitati u različitim tekstovima - svetim, medicinskim, no primarno umjetničkim (književnost i film). Upravo se u umjetnosti rađa specifičan odnos jurodivosti i položaja umjetnika koji se često poistovjećuje s njim ili ga uzima kao pozitivan primjer koji u sebi nosi "srž cjeline" poput Aljoše Karamazova. Ruski umjetnici i intelektualci često su mistično angažirani, za njih je sveto transcendentna ontološka stvarnost s kojom se može eksperimentirati. Međutim, treba razlikovati poimanje i položaj svetih luda u drevnoj Rusiji, zatim njihov položaj za vrijeme 19. stoljeća i prodora prosvjetiteljstva u Rusiji, te pozivanje na ovu tradiciju tijekom dvadesetostoljetne vladavine ateističkog i totalitarnoga komunističkog režima. U ovom se radu ne pristupa jurodivima kao folklornom kuriozitetu, nego se proučava odjek toga fenomena u određenom segmentu ruskoga intelektualnog života i njegovu utjecaju na rođenje takozvane ruske ideje (Nikolaj Berdjajev). U pitanju je pokušaj djelomične rekonstrukcije percepcija i refleksija na fenomen svetih luda, koje su često proturječne, i ni u kojem slučaju konzistentne, nego sačinjavaju raznolike kulturne konstrukcije. Esej problematizira način na koji fenomen jurodivih, karakterističan za rusku narodnu kulturu, u jednom zanimljivom povijesnom trenutku postaje isprepleten s mišlju ruskih intelektualaca poput Dostojevskog, Berdjajeva i Tarkovskog, dajući formu za religioznu koncepciju umjetnosti i specifično viđenje položaja umjetnika kao jurodivog "koji se danju ruga svijetu, da bi ga noću oplakivao".

\section{OD HAGIOGRAFSKE TRADICIJE DO NESLUŽBENOG PRAVOSLAVLJA}

Jurodivi ili "svete lude" (lude Krista radi) zauzimaju važno mjesto u ruskoj religijskoj tradiciji. Povjesničar Jevgenij Golubinski definira jurodivog kao "čovjeka koji se pretvara da je idiot i luđak radi Boga, te podnosi zlostavljanje i poniženje od strane drugih ljudi, da bi ih smiono razotkrio i osudio grešnost" (Golubinski, prema Murav 1992:177). Jurodivost je naizgled nerazumno ponašanje u religijske svrhe preko kojeg se prenosi i ostvaruje značajan dio ruske narodne baštine. Slavistica Harriet Murav ističe kako je njezino temeljno obilježje "preuzimanje ludila ili bezumnosti kao asketskog čina samoponiženja" (Murav 1992:2).

Međutim, persona jurodivog čak ni u granicama kršćanske civilizacije nije jedinstvena. Naime, jurodivi su postojali već u Bizantu iz kojeg je kršćanstvo i stiglo u drevnu Rusiju. Pisac i stručnjak za starorusku kulturu Jevgenij Vodolazkin ipak ističe kako su se jurodivi "najviše ispoljili upravo u Rusiji", što povezuje s ruskom sviješću za koju je, tvrdi, karakterističan upravo "osjećaj za iracionalno" (Vodolazkin 2013). Ovo zvuči pomalo esencijalistički, međutim već je poznati religijski filozof Nikolaj Berdjajev 
skovao termin ruska ideja (Berdjajev 2006) kako bi naglasio religioznu i mističnu crtu koja je prožimala rusku intelektualnu, umjetničku i filozofsku scenu 19. i početka 20. stoljeća. Riječ je zapravo o zanimljivom spoju pučke i elitne kulture.

Jurodive se često percipira samo kao ekscentrike, čudake, međutim oni predstavljaju svetost u svojoj najvišoj manifestaciji. "Oni su svetost koja ne želi biti spoznata i zato na sebe stavlja masku lude" (ibid.). U tom smislu oni bježe od slave; narodna izreka o jednom poznatom ruskom jurodivom kaže da se "danju rugao svijetu, a noću ga je oplakivao" - i molio za njegovo spasenje. Jurodivi su naime poznati po tome da su prekidali sve veze s društvom, napuštali svijet u činu žrtve, odricanja i molitve - po uzoru na Krista, oni su "umirali za svijet" (ibid.). Narodna predaja i hagiografije često ističu njihov asketizam - brojne su priče o jurodivima koji su hodali goli i bosi čitavu godinu, spavajući u štali i jedući otpatke. S jedne strane oni se izruguju samima sebi i čovjeku, no s druge strane potpunim negiranjem vlastite ličnosti oni pokušavaju dostići potpuno sjedinjenje s Bogom. Poput antičkog Diogena (mogli bismo reći protojurodivih), oni s upaljenom svijećom usred bijelog dana traže čovjeka, no ne nalaze ga. Jurodive su često tukli i ubijali, a pogotovo su ih djeca ismijavala (iako se uvreda jurodivog u narodu smatrala posebnim grijehom). Osim po proricanju jurodivi su poznati i po demaskiranju lažnih proroka i velikaša, te često dolaze u sukob sa službenim vlastima. Slavni je slučaj jurodivog Nikole Salosa ${ }^{1}$ koji je, kada je car Ivan Grozni razorio Novgorod i krenuo na Pskov, jedini imao hrabrosti da mu se suprotstavi, na prvi pogled suludom gestom naime, ponudio je caru komadić sirovog mesa. Ivan se uvrijedio i istaknuo kako ne jede meso za vrijeme posta, međutim Nikola mu je pronicljivo i prijekorno odgovorio kako radi i mnogo gore - jede tijela kršćana (ibid.).

Važna karakteristika jurodivih jest i da se za njih u narodu smatralo kako "vide ono što drugi ne vide" - Vodolazkin prepričava kako su često bacali kamenje na kuće pobožnih ljudi (ibid.), dok su mirno promatrali kuće notornih grešnika. Poput sibirskih šamana čija je religija² ostavila svoj trag u Rusiji, oni vide svijet "svetoga" koji je nedostupan prosječnim ljudima, te mogu voljno uspostaviti vezu s nevidljivim. Za šamane se, poput jurodivih, također često smatralo kako su u pitanju prevaranti ili poremećene osobe, a i često su bili dio etnocentrističkih rasprava o "primitivnom mentalitetu" čiji se tragovi mogu naći u duševnih bolesnika.

Jurodivima su u narodu pripisivali i razne natprirodne moći (proricanja, izlječenja itd.). Ono što ostaje najspornije jest priroda njihova "ludila" - prave li se oni svjesno, proračunato ludima ("stavljaju masku lude") ili su pak takvima rođeni i zbog toga odabrani.

\footnotetext{
${ }^{1}$ Saloi na grčkom znači sveta luda. Prvih šest kanoniziranih jurodivih Rusija je naslijedila od Bizanta.

${ }^{2}$ lako se često raspravljalo možemo li smatrati šamanizam religijom, etnolog Michel Perrin zaključuje kako šamanizam jest "neka vrsta religije, smatramo li religiju stanovitom predodžbom svijeta koju ne možemo lučiti od radnji što proizlaze iz vjerovanja koje ona ustanovljuje" (Perrin 2010:23).
} 
U ruskoj je kulturi naime prisutna tradicija da se za ljude koji su rođeni slaboumni ili mentalno zaostali smatra kako se kroz njih provodi "božja volja" i da su kao božji ljudi obdareni proročanskom moći. Upravo zbog toga što su ostali na razini bezazlena djeteta Bog in smatra dostojnima svojih tajni. Takav jurodivi jest recimo Irma Rauš iz Andreja Rubljova Tarkovskog, ili pak Eva Ras u Biće skoro propast sveta Aleksandra Petrovića. Ovaj podtip jurodivih treba strogo razgraničiti od hagiografskog tipa, tj. svjesnog hinjenja ludila kao religioznog čina. Jurodivi hini ludilo kao asketski čin samoodricanja, skriva svoju svetost pod maskom demoničnog ludila - u tome je paradoks hagiografija. Međutim, nazori puka često se razilaze od nazora službene crkve i hagiografa u pogledu svetosti i identiteta jurodivih. Granica je sve nego strogo određena, i često dolazi do raznih pretakanja. Poput sibirskih šamana, jurodivim se također može postati spontano, tj. božanskim odabirom ili pak svojevoljno aktivnom potragom. Ključno je otvaranje prema drugom svijetu koje se može potaknuti, katalizirati, ali ne i proizvesti na ljudski način (Perrin 2010:28). Ipak, ne treba prenaglašavati šamanističke elemente. Jurodivost ostaje unutar tradicije kršćanskog pravoslavlja, ali s onu stranu službene ortodoksije gravitirajući prema neslužbenoj pučkoj pobožnosti i heterodoksiji. Kao što pokazuje duga povijest mistike u kršćanstvu, Crkva strogo odvaja sveto i profano, vidljivo i nevidljivo, te će ga često gledati s nepovjerenjem ili odbaciti, prije nego što ga, u određenim iznimnim slučajevima, uzveliča. Iz perspektive naroda svećenik je u usporedbi s jurodivim obični službenik. lako ima naravno i jurodivih koje je crkva priznala, više je onih koje štuje narod a nisu naišli na odobravanje službenih crkvenih autoriteta, s kojima štoviše često dolaze u sukob, kao i s carskom vlašću.

lako koncept "mudre ludosti" nije rezerviran isključivo za istočno pravoslavlje, ipak se ne može osporiti poseban status i distinktivnu tradiciju jurodivosti kao posvećenog načina života unutar/izvan ruske pravoslavne crkve. Ruska pravoslavna crkva službeno je kanonizirala 30-ak svetaca iz redova jurodivih. Točan broj ostaje kontroverzan, a Harriet Murav pokazuje kako je rana povijest jurodivih (između 14. i 17. stoljeća) problematična, jer jako malo znamo o njima osim onog što su zapisali hagiografi, dakle strogo unutar koncepata i kategorija tadašnjega dominantnog religijskog okvira (Murav 1992:2). Službena verzija glasi kako jurodivi, kao i svi sveci, nastoje svojim primjerom imitirati Krista. Međutim, ono što ih izdvaja od drugih svetaca njihova je nesvakidašnja spremnost na prihvaćanje patnje i poniženja koje namjerno izazivaju svojim (tobožnjim) ispadima ludila. Jurodivi su bili i važni akteri u presudnim moralnim dramama ruske povijesti, kako pokazuje povjesničar i pisac Nikolaj Karamzin - njihova ludost služila im je da prokažu tiraniju i zle čine careva (ibid.). U pitanju je jedan tipično ruski mit čija je utemeljenost na činjenicama diskutabilna, međutim upravo je ova provokativna, kritički nastrojena uloga jurodivih najviše fascinirala ruske mislioce i umjetnike 19. i 20. stoljeća, poput Dostojevskog. Paradigmatičan je već 
spomenuti slavni slučaj Nikole Salosa i cara Ivana Groznog.

lako su bili prisutni već u Bizantu, najveći broj kanoniziranih jurodivih i od strane ruske pravoslavne crkve službeno priznatih svetih luda pojavljuje se u razdoblju od 15. do 17. stoljeća. Među najvažnijima su Prokopij iz Ustjuga, Izidor iz Rostova, Maksim i Vasilij iz Moskve, Nikolaj iz Pskova i Mihail iz samostana u Klopskom. Jurodivost je u tom razdoblju bila usko povezana s novom državnom ideologijom koja se postupno formirala nakon pada Konstantinopola. Crkva je tada stavljena u službu moskovskog državnog centralizma i vizije Rusije kao Trećeg Rima, posljednjeg bastiona pravoslavlja - Iokalni sveci postaju simboli nacionalnog identiteta. Važnu ulogu pritom su imali jurodivi koji su postali važan dio sakralizacije i regulacije svakodnevice. Giles Fletcher opisuje in kao "pustinjake koji hodaju goli i govore što im je na srcu bez ikakvih posljedica" (Fletcher, prema Murav 1992:19). Jurodivost lagano jenjava u 17. stoljeću nakon Raskola koji je proizveo brojne sektaše, poznate pod nazivom stari vjernici, a do radikalne transformacije dolazi reformama Petra Velikog. Sveti Sinod postaje vladajuće tijelo Crkve koja postaje inkorporirana u državu. Sinod izdaje niz strogih edikta protiv prakse jurodivosti i njezina modela askeze - čini se da u ruskom zaokretu prema modernosti nije bilo mjesta za svete lude. Njihova paradoksalnost sastoji se u tome što su proglašeni ili ih se smatra svecima iako naizgled ne posjeduju nijednu od karakteristika koje se pripisuju svecima - oni nemaju ni status mučenika ni čudotvoraca, rijetko su osnivali samostane ili bili pripadnici crkvene hijerarhije. lako asketi, njihovo ponašanje često je bilo (naoko) antiasketsko, štoviše razuzdano. Nije ih lako uvrstiti u standardne kategorije religioznog kanona.

Hrvatski etnolog Žarko Španiček u knjizi Slavonski pučki proroci i sveci iznosi niz primjera lokalnih karizmatika, od Ive Gavranovića kojeg su u narodu zvali Sveti Ivo, do vidovitog samoubojice Tune vrača. Studije pružaju zanimljive uvide o odnosu službene i neslužbene religije, a izjave Španičekovih kazivača bile su indikativne jer se u velikoj mjeri poklapaju i s onima iz studija o jurodivima. Poput slavonskih pučkih svetaca (usprkos očiglednim razlikama), i jurodivi obitavaju na ambivalentnom teritoriju između službene religije i neslužbene religioznosti. Scenarij obraćanja gotovo je istovjetan. Izabrani osjeti nadahnuće, iako drugi misle da je lud, on je uvjeren u istinitost i zbilju svojih vizija. Primjerice, Ivo Gavranović koji se, obučen u građansko odijelo ali bosonog, iz vedra neba uputio u 40-ak km udaljeno mađarsko proštenište. Potom nastupa velik preokret u kojem Ivo prestaje raditi kao kovač i posvećuje se svojem mističnom pozivu. Prijelom predstavlja razdoblje odvajanja od ranijega profanog života, vrijeme unutarnjeg pročišćavanja i pripreme za božanski poziv. Duhovna izolacija i odvajanje jurodivih od zajednice analogno je postupcima sibirskih šamana koji su se na taj način pripremili da ponovno uđu u društvo kao proroci i iscjelitelji.

Ambivalentnost pozicije kao kod šamana, istodobno izaziva strah i poštovanje. Mary Douglas pokazuje nam kako je ovo antropološka konstanta. Sva društva teže redu, 
no to ne znači da bezuvjetno osuđuju nered i poremećaj. lako je destruktivan prema prevladavajućim društvenim obrascima, nered je i potentan - označava istovremeno i opasnost i moć (Douglas 1966:95). U mračnim, kaotičnim predjelima uma (snovi, fantazije, manije) ljudi su tijekom svih doba tražili moći i istine koje se ne mogu postići svjesnim naporom. Iznimne sposobnosti i moć iscjeljivanja stječu oni koji mogu umaknuti kontroli razuma i zaći u mutne, mračne predjele vlastita uma, te oni koji izbivaju izvan društva napuštajući njegove konvencije. Douglas nabraja brojne zanimljive primjere kod domorodaca na Andamanskim otocima uobičajeno je da pojedinac napusti skupinu i luta šumom poput luđaka, a kad se vrati nakon duljeg izbivanja stekao je okultnu moć iscjeljivanja (ibid.). Oni koji se vrate iz nedostupnih, nepoznatih duhovnih i fizičkih krajolika posjeduju moć koja nije dostupna običnim ljudima koji ostaju pod kontrolom vlastita razuma i društva. Obje ove karakteristike označavaju i ruske jurodive. Otuda djelomice proizlazi fascinacija koju izazivaju i povjerenje koje im narod ukazuje.

lako su priznati kao važan dio pravoslavne tradicije, jurodivi kao i drugi primjeri pučke pobožnosti po mnogo čemu odudaraju od službenoga vjerskog naslijeđa. Kako se postaje jurodivi? Jedini odgovor koji se nameće jest njihovo snažno uvjerenje o božanskom pozivu koji im je određen. Stoga je prikladno da Rusija koja, kako Berdjajev sugerira u svojoj utjecajnoj studiji Novo srednjovjekovlje, nikad nije izašla iz srednjeg vijeka, dijeli i njegovu ambivalenciju prema svetome - običan puk teško je razlikovao dobra od zlih čuda, magija je prožimala službenu crkvenu liturgiju, a lažni proroci svih vrsta najčešće su se predstavljali kao prerušeni sveci (Le Goff 1973:200). Ipak jurodivi po mnogo čemu odudaraju i od konvencionalne pučke teologije, koja se odlikuje ponajprije vjerom u čuda. Čuda su najpristupačnija puku jer in doživljava kao produžetak vlastite tradicije narodnog čarobnjaštva (Gurevič 1987:92-93, 95), međutim jurodivi nisu izvodili nikakva čuda, a nije im svojstveno ni moralno savršenstvo i čistoća koje su apostrofirali duhovni oci (barem ne na prvi pogled). Isticali su se svojim odricanjem, askezom i spremnošću na patnju - svim ovim karakteristikama na osebujan su način nasljedovali Krista i potpuno se sjedinjavajući s njim utjelovljavali su karakteristično rusku težnju totalnosti.

Stvari dodatno komplicira što službena i pučka kultura obje dijele ambivalentnost prema svetome, te nikako nisu razdvojene i suprotstavljene kako je mislio Bahtin, nego se višestruko prožimaju. Španiček navodi kako je do 9. stoljeća utvrđivanje svetaca u Europi, pa i Rusiji bilo krajnje neformalno te je puk vodio glavnu riječ. Međutim, od 12. stoljeća pa nadalje crkvene vlasti sve više preuzimaju kontrolu i centralizaciju nad utvrđivanjem svetosti (Španiček 2002:258). No kako tijekom cijeloga srednjeg vijeka nije postojao općeprihvaćeni kanon svetosti, pučke zajednice razvijale su vlastite, ponekad i osebujne interpretacije svetosti (ibid.:259). Pritom nerijetko inkorporiraju i pretkršćanske, u slučaju Rusije, šamanističke elemente. 
Kako demonstrira Michael Goodich, jurodivi pripadaju općoj pojavi neslužbenih svetaca u kasnom srednjem vijeku. Često su bili ekscentrici koji su se isticali neobičnom odjećom, te bizarnim i nekonvencionalnim ponašanjem pa bi ih ponekad zamijenili za heretike (Goodich 1982:194). Međutim, jurodivi odudaraju od većine konvencionalnih definicija kako crkvenih tako i pučkih svetaca. Aron Gurevič navodi kako katolički sveci (a isto se može reći za pravoslavne) kao predstavnici crkvene organizacije nisu mogli u potpunosti odgovoriti potrebama i očekivanjima puka, jer su ih sputavale službene dogme. To je otvorilo pojavu drugog tipa sveca koji nisu bili službeno nepriznati. Pučki sveci često su i sami potjecali iz mase te su izražavali njezina nadanja i raspoloženja neposrednije i potpunije od kanoniziranih svetaca (Gurevič 1987:102-103). Ipak, jurodivi se razlikuju od ovih srednjovjekovnih narodnih svetaca po tome što oni ne traže sljedbu te priznanje i poštovanje za sebe. Upravo suprotno, za razliku od ovih "lažnih proroka" oni se odriču od slave, mada često prkose crkvenom i carskom autoritetu. Kao što Španiček pokazuje, ambivalentnost je osnovna značajka odnosa naroda prema pučkim svecima i ona uključuje povjerenje i poštovanje s jedne strane, te sumnju i ignoriranje s druge strane (Španiček 2002:266). No ako slijedimo Bahtina, ambivalentnost je još od najranijih stupnjeva kulture karakteristična za pučki odnos prema svetome (Bahtin 1978). Stoga možemo zaključiti, poput Španičeka, da upravo ta dvoznačnost odnosa prema pučkim svecima, u ovom slučaju jurodivima, pokazuje da ih je narod stvarno doživljavao kao svete osobe. Ismijavanje jurodivih ne znači negaciju njihova statusa, nego naličje afirmativnog odnosa prema njima (Španiček 2002:269). Svojim životnim stilom, duhovnom usmjerenošću na onostrano i osobnim značajem oni odudaraju od svoje okoline - međutim, njihova svetost nikako nije samo individualna kvaliteta, nego i društvena kategorija jer se razvija u aktivnom odnosu između pojedinca i zajednice u kojoj djeluje (ibid.:264).

\section{JURODIVI I LUDILO; DOSTOJEVSKI I NADAHNUTI LUĐAK}

Pri proučavanju svetih luda ne možemo se oslanjati samo na hagiografije i službene crkvene izvore. Fenomenu svetih luda pristupalo se posljednjih godina iz različitih perspektiva, sociološke, antropološke i povijesne, te interdisciplinarne. Htjela bih navesti nekoliko ključnih autora i istaknuti ključne točke njihova pristupa. Ewa Thompson u Understanding Russia: The Holy Fool in Russian Culture (1987.) tvrdi kako je ruski nacionalni identitet uvelike oblikovala važna uloga koju su jurodivi tijekom stoljeća igrali u ruskoj kulturi. Ona smatra kako su mnogi istraživači prenaglašavali njihov kršćanski karakter, zanemarujući ono što naziva njihovom poganskom naravi koja proistječe iz šamanizma. Kao primjer navodi Izaka, prvoga ruskog jurodivog čiji opis u hagiografiji uvelike podsjeća na ponašanje tijekom šamanističkih rituala (Thompson 
1987:98). Drugi istraživači pristupali su fenomenu jurodivih pod utjecajem medicinske psihologije i racionalističkog svjetonazora tumačeći ga kroz prizmu mentalne bolesti. Harriet Murav sasvim opravdano sumira temeljnu manjkavost obaju ovih pristupa - oni postavljaju pitanje što se stvarno dogodilo, umjesto da se pitaju što su hagiografi koji su bilježili ovaj fenomen mislili da se dogodilo i što je on u danom kontekstu značio za njih. Kako različita društva interpretiraju pojmove kao što su bolest, ludilo i svetost itekako se mijenja kroz različita razdoblja - antropolozi najbolje znaju kolika je poroznost granica između triju pojmova. Stoga je upravo antropološki pristup ključan u odmaku od "povijesnih činjenica" prema interpretaciji načina na koji su hagiografi konstruirali svetost jurodivih, ali i načina na koji su ruski intelektualci poput Dostojevskog, Tolstoja i Berdjajeva konstruirali svoje mentalne svjetove pod utjecajem ovoga važnog fenomena. Elementi službene i neslužbene religije, učene i pučke kulture prožimaju se na kompleksne i ambivalentne načine a sve u potrazi za izgubljenom duhovnošću. Slažem se s Murav kako A. M. Pančenko donosi najzaokruženiji prikaz fenomena svetih luda. Potkrepljujući ga nizom povijesnog materijala iz pučke kulture, folklora, slikanja ikona i dvorskog života, uspijeva rasvijetliti kulturne norme vremena u kojem je jurodivost doživjela svoj procvat. Pančenko iznosi zanimljiv argument kako "svete lude treba gledati kao svojevrsne performere i inačicu srednjovjekovnog uličnog teatra koji se odvija na razmeđu dvaju svjetova - rigidne hijerarhije crkve i države te 'kulture smijeha' utemeljene u folkloru" (Murav 1992:23). Pančenko naglašava i dinamičnu interakciju između jurodivog koji izvodi performans i publike koja ga promatra: oni i sami postaju akteri tako što vrijeđaju i zlostavljaju sveca - još jedan paradoks. Ključan je čin prepoznavanja, sve na svecu upućuje na potpunu suprotnost; njegov kostim, diskurs i geste podložne su konfliktnim interpretacijama, a njegova goloća za jedne je znak demonskoga, a za druge anđeoske bestjelesnosti (Pančenko 1976:118). No odnos i uloga jurodivih u zajednici sve je nego destruktivna. Usprkos njegovu odvajanju i odricanju od svijeta u svojem izvornom obličju jurodivi igra itekako važnu ulogu u zajednici, dijeli njezine središnje vrijednosti utjelovljene u pravoslavnoj crkvi - on približava božju sliku čovjeku, nudeći primjer kojim su mnogi veliki ruski stvaraoci postali opsjednuti i sami htjeli utjeloviti, također bježeći od slave primjer Tolstoja tu je možda najočitiji. No istodobno jurodivi utjelovljuje i sliku posrnulog čovjeka, čovjeka koji je najudaljeniji od Boga.

Jurodivost je, kao što hagiografi objašnjavaju, utemeljena u određenim paragrafima Novog zavjeta, od kojih je ključna "Pavlova poslanica Korinćanima": Mi smo lude Krista radi (1 Kor. 4:10). Jurodivi Simeon preuzima na sebe sliku roba, kako bi spasio roba. (Simeon je nakon 29 godina provedenih u pustinji odlučio otići u grad kako bi se rugao svijetu. Uzeo je pseći leš i vezao ga oko struka, djeca su trčala oko njega i derala se kako dolazi ludi svećenik.) Svetac se odriče svoje vlastite ličnosti i individualnog života radi života koji drugi mogu ponoviti (Murav 1992:29). Međutim, svijet ne prepoznaje sveca u 
tobožnjoj ludi - luđaci tuku sveca kao da je sam lud. U ludom svijetu teško je prepoznati sveca u tobožnjem luđaku - to je smisao parabole.

Harriet Murav upućuje na važnost iščitavanja fenomena izvan hagiografske reprezentacije jurodivosti kao samovoljne askeze i religioznog čina. Fenomen jurodivih treba sagledati unutar širega antropološkog konteksta povijesti stavova ludila u Rusiji, te prevladavajućih stavova i percepcija. Devetnaestostoljetni etnograf Vladimir Ivanovič Dalj u svojem rječniku piše o "ludama od rođenja" (jurodivima) koje narod smatra božjim Ijudima, te njihovim nesvjesnim radnjama često pripisuju dublje značenje, predosjećaj ili proricanje (Dalj, prema Murav 1992:3). Ipak, ovaj poseban odnos ruskog naroda prema ludilu, njegov slavni "osjećaj za iracionalno" nije tako samorazumljiv kako neki autori sugeriraju, a nikako ne znači da se svi oblici ludila smatraju božanskim blagoslovom, nego samo određeni specifični vid. Dok je etnolog Dalj ovo štovanje "luda od rođenja" smatrao šarmantnim obilježjem ruskog folklora, drugi su, poput Ivana Gavriloviča Prižova, bili zgroženi i smatrali ovu folklornu tradiciju narodnom izopačenošću i trijumfom neobrazovanosti i neznanja. Prižov je posvetio nekoliko podugačkih pamfleta razotkrivanju licemjerja i neznanja 26 jurodivih, koji su svojedobno bili miljenici kako priprostih seljaka tako i moskovskih visokih krugova. ${ }^{3}$ Za neke piše da su prevaranti koji svojim predviđanjima i tobožnjim iscjeljivanjima iskorištavaju lakovjerne, dok za druge tvrdi kako su uistinu bili maloumni te su njih same iskorištavali njihovi skrbnici i zarađivali na njima (Murav 1992:5). Prižov je htio očistiti rusku kulturu od ovih folklornih elemenata koje je smatrao nepoćudnim, te je bio zgrožen "leglom fanatizma, neznanja i razvrata koje je našao u samom krilu pravoslavlja" (Prižov, prema Murav 1992:6).

Kontroverzni položaj svetih luda dodatno komplicira rođenje klinike i osvit medicinske psihologije koji u Rusiju stiže tek u kasnom 19. stoljeću. Više se ne raspravlja o stvarnim i lažnim svetim ludama, nego se čitav fenomen sagledava u vidu patologije. "Ono što bi nekoć bilo smatrano asketskim činom ili znakom karizmatične sposobnosti, sada se moglo dijagnosticirati kao simptom bolesti i interpretirati kao devijacija od normalnog", kaže Murav (1992:5) inspirirajući se studijama slučaja nekoliko znamenitih jurodivih iz arhiva moskovske Preobraženske bolnice. Foucault nam pokazuje smjer u kojem se kretala desakralizacija u doba klasicizma (Foucault 2009, 2013). Još u renesansi za luđake se smatralo kako posjeduju mudrost i dostupno im je znanje o ograničenosti ovozemaljskog svijeta - oni su često u literaturi razotkrivali pravu istinu o ljudima i razliku između njihove stvarne suštine i izvanjske pojave. U renesansnoj umjetnosti i literaturi luđaci itekako mogu općiti s razumom i racionalnim, međutim predstavljaju tajanstvene

\footnotetext{
${ }^{3}$ Najslavniji je Ivan Jakovljev Koreiša kojem je dijagnosticirana demencija, ali ga je svejedno velik segment ruske populacije štovao kao sveca. Razne interpretacije njegova slučaja ilustriraju, prema Murav, heteroglosiju koja je vladala u Rusiji u kasnom 19. stoljeću.
} 
sile kozmičke tragedije. Foucault demonstrira kako je ludilo koje je još od doba grčke tragedije bilo ključno sredstvo komuniciranja s višim silama te u doba klasicizma (koje je u Zapadnoj Europi kulminiralo u kasnom 17. i početku 18. stoljeća, dok u Rusiju stiže kasnije, u drugoj polovini 19. stoljeća) potpuno prognalo i isključilo ludilo. Ono prestaje biti znakom onostranoga i biva svedeno na "paradoksalnu manifestaciju nebivanja" (Foucault 2013:114). Ludilo se shvaća kao ništavilo, suprotno od bivanja, negacija razuma, te ga treba ukloniti iz društvenog poretka ne zato što predstavlja opasnost za nj, nego zato što u njemu za nj uopće nema mjesta (razum negira ono što ne razumije).

Na ovaj racionalizam reagira Dostojevski i ostaje suštinski jurodivi, za njega je ludilo i dalje sveto i označava one koji vide ono što drugi ne vide. Arhetip ruskog intelektualca toga doba zauzima dakle drugačiji stav prema fenomenu. Smatrao je kako se iskupljenje i cjelovitost ruskog društva može postići jedino posredovanjem između dvaju svjetova, onog ruske pučke kulture koja je lokus jurodivih i onog obrazovanih visokih klasa koja je lokus književnih salona. Položaj jurodivih koji poistovjećuje sa svojom ulogom kao umjetnika i autora, transformacija intelektualca u "svjesnu ludu" srž je ideološka projekta iza njegovih romana i novinarskog rada, uvjerljivo demonstrira Murav. Kao primjere jurodivih u romanima Dostojevskog, Murav navodi Sonju Marmeladovu u Zločinu i kazni, kneza Miškina u Idiotu, Mariju Lebijadkinu u Bjesovima, te Aljošu Karamazova i Zosimu u Braći Karamazovima (Murav 1992:7). Kroz način na koji Dostojevski u raznolikim tekstualnim konstrukcijama reprezentira i preoblikuje fenomen jurodivih kristalizira se njegov kompleksan odnos prema ruskom nacionalnom identitetu, odnosu pučke i elitne kulture (obrazovane elite i neobrazovani, ali "autentični” puk), ali i vlastitoj ulozi u ruskoj javnosti i generalnoj misiji intelektualca. Gledano iz ideološke i naratološke perspektive, Murav rezimira tri uloge koje sveta luda igra u svijetu romana Dostojevskog: "utjelovljuje otpor prema dobu pozitivizma i znanosti (riječi koje sam Dostojevski upotrebljava za doba u kojem živi); simbol je čovjekove izopačenosti i potrebe za iskupljenjem, te služi kao putokaz za potencijalnu budućnost ljudskog iskupljenja kroz odricanje od vlastitog ega" (ibid.:8). Pritom sam autor preuzima na sebe masku lude i prevodi kulturni fenomen u književnu formu romana. Murav polazi od i trezveno kritizira Bahtinovu teoriju karnevala. U Problematici poetike Dostojevskog Bahtin naglašava važnu vezu između karnevala i romaneskne strukture (Bahtin 1984) - roman naime imitira popularni spektakl svojom strukturom, ali i jezikom koji relativizira i parodira službeni jezik dominantne kulture koji teže centralizaciji i autoritativnosti. No dok Bahtin jurodivost kod Dostojevskog čita samo kao podvrstu karnevala, Murav naglašava kršćanski karakter misli Dostojevskog i njegova ideološkog projekta, njegovu religioznu, fundamentalno kršćansku misiju (Murav 1992:10). Sveta luda u karnevalskom duhu jest utoliko što priziva preobrat, međutim njegov konačni cilj jest iskupljenje i spasenje, a ne obrat radi samog obrata ona upućuje na put prema kraljevstvu neba. Također, kod Dostojevskog sveta luda nije 
folklorni arhetip koji stoji suprotstavljen službenoj kulturi i želi je razoriti, nego je pokušaj sinteze pučke i elitne kulture prožet religioznošću unutar koje su imitacija Krista i kršćanske vrijednosti ključne, no prije na tragu kategorije numinoznoga kako ga je definirao teolog Rudolf Otto (Otto 2006), nego u smislu službenog pravoslavlja. U interpretaciji Bahtina i drugih gubi se religiozna srž djela Dostojevskog te on u povijesti književnosti ostaje zapisan kao predstavnik realizma i neumorni analitičar najskrivenijih i mračnih kutaka ljudske duše. Međutim, njegovo "nalaženje čovjeka u čovjeku" esencijalno je religijska ideja i označava vraćanje odraza božanskog u čovjeku. Dostojevski vjeruje u kršćanski duh ruskog naroda usprkos (ili možda upravo zbog) njegove izvanjske neobrazovanosti i brutalnosti (Murav 1992:12). Murav smatra da njegove narativne strategije služe njegovoj teologiji, a ne obrnuto kako postulira Bahtin, te naziva njegove trope teologemima (ibid.:13). Međutim, Murav zanemaruje naglasiti kako njegovi tzv. teologemi nastupaju oštro protiv službene ortodoksije i ideologije Trećeg Rima, te on kroz jurodive zagovara nekonformističku, heterodoksnu religioznost.

Diskurs svete lude u romanima Dostojevskog potiče od njihove dobro znane karakteristike da "vide ono što drugi ne vide"; s jedne strane kenoza služi samopražnjenju/samo-poricanju, s druge strane ona je provokacija i izazov dominantnoj kulturi - romanopisac kao i sveta luda upućuje onkraj onoga što je neposredno vidljivo. Kao antimodernist Dostojevski kroz figuru svete lude nastoji "dekonstruirati dominantno zapadne, znanstvene i sekularne vrijednosti prema kojima se Rusija u svojem zaokretu prema modernosti počela oblikovati” (ibid.:14). Aljoša Karamazov i drugi ekscentrici pod utjecajem jurodivih trebaju služiti kao pozitivni uzori - poniženi i bijedni imaju priliku svojim primjerom nadići sami sebe, postići transcendenciju. No, Murav ističe kako nije uvijek lako razaznati tko je sveta luda, a tko je samo luda (ibid.:15). Baš kao i u šamanizmu u kojem je veliko pitanje postojanje ili nepostojanje vjerodostojne inicijacije, a u ovom je slučaju spontana, jer ortodoksija ne odgovara, zbog svoje sklerotičnosti, na sve potrebe vjernika. No to je dio teritorija jurodivih, igra opsjena i iluzija u kojima je transformacija i obnova dostupna samo onim najhrabrijima, spremnima na najveće odricanje.

Dostojevski svoje romane gradi na paradoksalnoj svetosti jurodivih - njegovi likovi poput svetaca trebali bi biti uzori za čovječanstvo, živuća imitacija "savršena čovjeka, tj. Krista". No na prvi (možda i drugi) pogled čini se da utjelovljuju sve što je karnalno, promašeno i demonsko, ono najgore u čovjeku, kao što u ruskoj pravoslavnoj teologiji hagiograf transformira naizgled grešni život svete lude u moralni exemplum. Pančenko i Murav pokazuju kako se u hagiografijama svetaca kao ključan nameće upravo problem prepoznavanja i podrazumijeva se aktivna, a ne pasivna uloga čitatelja - na njemu je da "upiše život sveca u svoju dušu i tijelo" (ibid.:31), na njemu je da napravi nužan izbor i prepozna sveca. Na sličan način Dostojevski od čitatelja svojih romana traži da 
razaznaju lažne lude od svetih luda i preuzmu odgovornost za svoje vlastito spasenje.

Kao što smo već vidjeli, ne postoji jedna jedinstvena kulturna definicija svete lude (jurodivog). Hagiografska tradicija sama po sebi obiluje paradoksima i proturječjima, a granica između onoga što se smatralo demonskim, a što božanskim, nadahnutim ludilom nikad nije precizno povučena. U 19. stoljeću (kada je Dostojevski stvarao) fenomen svete lude biva upleten u širi konflikt između tradicionalne i moderne kulture u kojem su sve veći prestiž fiziologije i medicinske psihologije, te nove kategorije normalnosti i abnormalnosti odigrali ključnu ulogu.

Murav pokazuje kako Dostojevski prisvaja i reinterpretira ruski model svete lude na tri razine - poradi narativne inovacije, izražavanja kulturne kritike i samoreprezentacije sebe kao autora (Murav 1992:171). Slično kao u originalnim hagiografskim izvorima likovi koji utjelovljuju svete lude opasno se približavaju svojoj suprotnosti, riječima Murav, "ludi koja se samo izruguje, a da ne moli za spasenje svijeta" (ibid.:172). Pozitivna utjelovljenja jurodivih, tako u njegovim romanima bivaju okružena mnogim demonskim ludama. Budućnost Rusije jest neizvjesna, no Dostojevskog zanima spasenje i božansko iskupljenje ruske povijesti - pritom na sebe preuzima ulogu jurodivog, kojeg njegovi kritičari vide samo kao običnu ludu. Time dolazimo do specifičnog viđenja pozicije umjetnika, ne kao mesije (wagnerovski tip) nego kao nadahnutog luđaka (jurodivog).

\section{JURODIVI I ANTIRACIONALISTIČKA PRIRODA FILMA - FILMSKE SLIKE KAO PUTOKAZ K DRUGOM SVIJETU}

Polako se kristalizira specifični ruski pogled na umjetnost i ulogu umjetnika, navodeći nas da uzmemo u obzir širi kontekst promišljanja stvaralaštva.

Poljska redateljica i filmska kritičarka A. M. Korycka promatra debitantski film slavnoga ruskog redatelja Aleksandra Sokurova Usamljeni glas čovjeka (1978.) kao pravoslavnu ikonu. Putovanje glavnog junaka Nikite interpretira kao put jurodivog koji se mora oduprijeti iskušenjima i savladati asketizam kako bi postigao svetost i duhovno prosvjetljenje. Poznat po meditativnim filmovima oniričke vizualnosti koji tematiziraju egzistencijalna lutanja i duševne tjeskobe, Sokurov je brzo prozvan nasljednikom Andreja Tarkovskog. Sam Tarkovski jedini je koji ga je branio tijekom progona od strane moskovske vlasti i sveučilišnih autoriteta koji su zabranili njegov diplomski rad. Film inspiriran književnim predloškom Andreja Platonova tek je 1987. godine (nakon Glasnosti) javno prikazan. Priča prati sudbinu dvoje mladih, Nikite i Ljube koji pokušavaju preživjeti u svijetu razorenom nakon građanskog rata. Korycka ilustrira kako Sokurov pomoću pretapanja i dugih, subjektivnih kadrova, tj. filmskom tehnikom dočarava različite faze Nikitina puta koji vodi prema Bogu i sve većem udaljavanju od drugih ljudi, tj. osjećaju 
stranosti i liminalnosti između života i smrti. Njegovo sjedinjenje s Bogom, vječnom ljubavi simbolizira njegov stvarni, no eterični odnos sa studenticom medicine Ljubom - njezina kuća stalno je obasjana suncem u kontrastu s mračnim prostorom kuće u kojoj obitava Nikitin otac (Korycka 2016:9). Ljubav dvoje likova analogija je božje ljubavi prema čovjeku, ona je čista, duhovna i vrlo vjerojatno nije uopće tjelesno konzumirana. Njihov odnos simbolizira "apsolutno jedinstvo", oni se stapaju u savršeno i cjelovito androgino biće, nalik božjoj slici (ibid.:10). Aleksandar Sokurov u jednom intervjuu definirao je umjetnost kao "čin otkrivanja arhetipa uklanjanjem zavjese. Umjetnik poput slikara ikona, ne stvara sam sliku nego samo skida zavjesu s bezvremene slike koja već postoji, on razotkriva skrivenu duhovnu stvarnost" (ibid.:10-11). Korycka pomno analizira način na koji Sokurov koristi filmsku tehniku za postizanje istovjetnog efekta: korištenje filtera, snimanje kroz osunčani prozor te osvjetljenje stvarnih svijeća u filmskom prostoru postižu intimnu atmosferu koja je prigušena, mutna i neuhvatljiva. Poput ikonostasa u pravoslavnoj crkvi vidljiv i nevidljiv prostor bivaju istovjetno povezani i odvojeni (ibid.:11), a Sokurov gledatelja poziva na aktivnu ulogu jer on uvjetuje umjetničko djelo (ovo podsjeća na hagiografe i Dostojevskog koji također pozivaju čitatelja da prepozna jurodivog i slijedi njegov primjer na putu za spasenje). Nikitin žrtveni ritual, ispunjen preprekama, ne odvija se u stvarnom, fizičkom prostoru, nego u metafizičkom, duhovnom prostoru, a Sokurov nam to pokušava dočarati. S tim je povezano i rusko narodno praznovjerje o zrcalu kao vodilici duše prema svojem nesvjesnom i svojem stvarnom odrazu (i njegov uzor Tarkovski često kadrira pomoću ogledala - npr. filmovi Solaris i Zrcalo). Korycka u svojem tekstu zaključuje kako je Sokurovljev simbolizam itekako utemeljen u "ruskoj specifičnosti i pravoslavnoj tradiciji koja putem ikona uči gledatelja da pogleda u limb, u samu dubinu, i iz mraka uzdigne pogled prema visinama" (ibid.:13).

Sažimanje ove misaone struje koja u Rusiji vidi utjelovljenje osjećaja za iracionalno pruža nam religijski filozof Nikolaj Berdjajev. Berdjajev kao i mnogi drugi mislioci smatra kako je osobitost sudbine Rusije $u$ tome što ona nikad nije $u$ potpunosti prigrlila humanističku kulturu novog doba i s njom povezan racionalistički svjetonazor, formalno pravo i formalnu logiku. Rusija, tvrdi Berdjajev, nikad nije do kraja izašla iz sakralne epohe, tj. srednjovjekovlja (Berdjajev 1991:15). U njegovoj interpretaciji čak i komunistički režim ima sakralni karakter, on je pseudoreligija i pseudoteokracija. Berdjajev u skladu s ovom strujom misli zaključuje kako moderno doba objelodanjuje kako "Ako nema Boga, nema ni čovjeka." (ibid.:14). Zagovara religijsku koncepciju kulture, jer smatra kako religija ne može biti privatna i autonomna stvar, kao što ni ostale sfere kulture ne mogu biti autonomne. Ličnost čovjeka može biti ukorijenjena samo u univerzalističkim idejama, tu nalazi svoje ontološko uporište i viši sadržaj. Individualizam zapadnog tipa samo je površinsko iskrivljenje ličnosti koje je odvojeno od bivstva, te je njime čovjek odijelio sebe od drugih ljudi i od svijeta - treba prijeći od puke, formalne slobode do 
suštinske slobode (ibid.:20). Spoznaja života i bivstva uzmiču pred predmetnošću koja sve više prevladava. Berdjajev upozorava kako se sva energija troši na spoljašnost (tipična misao za jurodivost) te upozorava na ugasnuće duhovna stvaralaštva (ono isto koje Tarkovski i Sokurov nastoje obnoviti). Berdjajev se također poziva na simbolizam kulture koji je u krizi. Kultura (država, crkva, umjetnost, moralni običaji) je po svojoj prirodi simbolična, u njoj su dani znaci onostranog, duhovnog života, međutim ne mogu se kroz nju neposredno realizirati - one daju samo znakove preobraženja. Civilizacija 19. i 20. stoljeća (možemo dodati i 21. stoljeće) svojom slijepom usmjerenošću na materijalnost i tehniku poriče sakralnu dimenziju kulture i pravi smisao njezine simbolike (ibid.:33). Tipično ruska opsesija jest da se mora iznaći novi duhovni princip organizacije vlasti i kulture. Berdjajev sumira temeljne preokupacije Dostojevskog, religijski tip ateizma koji je izniknuo u Rusiji i stvarnu prirodu ruske revolucije; "Dostojevski je pojmio da je socijalizam u Rusiji religiozno pitanje, pitanje ateističko, da ruska revolucionarna inteligencija nije nikako zanesena politikom, već spasenjem čovječanstva bez Boga." Ponovno se poziva na religijsku prirodu ruskog naroda. Čak i kad posjeduje materijalna bogatstva u dubini duše ruski čovjek smatra da je bolje otići u samostan ili postati skitnica (ibid.:65). Prema Berdjajevu, ruska ideja zajednička je komunistima i socijalistima, ali i velikim konzervativnim misliocima poput Tolstoja, Dostojevskog, Fjodorova, Leontjeva i Solovjeva - ona je podjednako neprijateljski nastrojena prema buržujskim vrijednostima upisanim u našu modernu civilizaciju.

Veliki ruski redatelj Andrej Tarkovski u svojem dnevniku, predavanjima i intervjuima, a pogotovo u svojoj knjizi Vajanje $u$ vremenu bavi se prirodom filma i njegovom ulogom u današnjem svijetu, te razlaže svoju osebujnu filozofiju umjetnosti, u kojoj se itekako vidi ruskog podneblja i njegove specifične religijske tradicije (Tarkovski 1991, 1999). Tarkovski smatra kako pravi film mora biti "cjelovita, zaokružena slika univerzuma koja za razliku od pojmovnih konstrukcija filozofije ne traži potporu i opravdanje u racionalnoj, već u intuitivnoj sferi naše ličnosti" (Vučinić 2013:1). Tarkovski također njeguje naglašeno religioznu koncepciju umjetnosti - ona je "hijeroglif apsolutne istine" i "detektor apsoluta sui generis" (ibid.:2). Umjetnost čini beskonačnost dodirljivom, vjera i stvaralaštvo dva su temeljna principa poetike Tarkovskog, dvije manifestacije iste suštine, pravi umjetnik stvara intuitivno (on ne traži, nego nalazi - poput dječaka Boriške koji intuitivno izrađuje veličanstveno zvono u Andreju Rubljovu). Umjetnost putem simbolizma razotkriva smisao ljudskog postojanja, a njega prema Tarkovskom treba tražiti u duhovnom uzdizanju i usavršavanju, te postizanju harmonije s drugim ljudima i univerzumom. Navedene ideje Tarkovskog u članku Tarkovski i smisao umetnosti kontekstualizira u dugu tradiciju mističke estetike i promišljanja umjetnosti koja je prisutna u Rusiji, ali i u cjelokupnoj zapadnoj kulturi (ibid.:3). Materijalni razvoj nije praćen duhovnim napredovanjem (temeljna preokupacija). Tarkovski stvaranje shvaća kao težak i prinudni čin; dug i 
iskupljenje, a umjetnik je tragična figura - na njemu nije da bude gord i ponosan, nego da služi. Mnogo je tu karakteristika jurodivih, kao i kod svih glavnih junaka njegovih filmova vizija koju dijeli s misliocima kao što su Kierkegaard i Nietzsche koje povjesničar religije Jaroslav Pelikan navodi kao istaknute primjere "svetih luda" (Pelikan 2001). Vučinić pak ističe kako je ideja o umjetniku kao svojevrsnom proroku koji služi objavljivanju Istine i Božanskoga u svijetu prisutna u ruskoj poeziji još od Puškina pa sve do Pasternaka. Tarkovskog užasava što su umjetnost i zapadna civilizacija izgubile vezu sa sakralnim i magijskim koje su bile njezin glavni izvor. Kao svoje uzore u svijetu umjetnosti izdvaja Tolstoja, Bressona, Bacha i Leonarda, no zanimljivo je njegovo obrazloženje izbora - u pitanju su "božanski bezumnici" koji "nisu stvarali uz pomoć glave" (ibid.:6). Umjetnost Tarkovskog odražava njegovu žudnju za izgubljenim Apsolutom i njezin je cilj da pripremi čovjeka za smrt, učinivši ga sposobnim za okretanje k dobru (ibid.:7). Nigdje ovo nije tako evidentno kao u njegovu posljednjem filmu Žrtvovanje (1986.) koji je nastao neposredno prije no što je umro od raka pluća, u pitanju je njegov oproštaj od ovog svijeta i umjetnički testament. Film je sinkretička umjetnost u kojoj se sugestivno artikuliraju i sažimaju različiti slojevi pojedinačnog i kolektivnog pamćenja. Pogotovo se u kadru, kako objašnjava u svojoj knjizi Vajanje u vremenu, može prepoznati specifična filozofija života određenog autora i neponovljivost njegova svijeta. "U kadru se razotkriva i sažima jedinstveni modus korespondencije i harmonije između vremenitosti pojedinačnog bića i beskonačnosti univerzuma" (ibid.:12). Smisao filmske poetike Tarkovskog treba tražiti u duhovnom razvoju junaka njegovih filmova - oni se kroz bol i patnju uzdižu do spoznaje svijeta. Međutim, ta spoznaja nalazi se "s one strane zdravorazumskog, racionalnog mišljenja, ona je, čak, u svojoj osnovi jurodiva", konstatira Vučinić (ibid.:13). Njegovi likovi božanski su bezumnici kao i njegovi umjetnički uzori. Tarkovskom su bliske ideje Berdjajeva i Dostojevskog o umjetnosti kao teurgiji, kao bogočinjenju. U njegovu umjetničkom testamentu, filmu Žrtvovanje, glavni junak Aleksander glumac je koji je napustio kazalište jer je izgubio vjeru u svoj poziv. Kako bi ispunio zavjet koji je dao Bogu i spasio svoje bližnje i svijet, on poput jurodivog spaljuje svoju kuću i žrtvuje svoja materijalna dobra, ugled i ljubav porodice, a i vlastiti razum. Tarkovski u svim svojim filmovima (recimo, Stalker i Solaris) nastoji uputiti na mogući put kako da se uravnoteže naše duhovne i materijalne potrebe. U prvom filmu nastalom nakon što je našao utočište u Italiji, Nostalgija (1983.), glavni junaci - ekspatriotski ruski pjesnik Andrej Gorčakov i njegova srodna duša, lokalni čudak Domenico - također su svojevrsni jurodivi; oni su potpuno nezainteresirani za svakodnevni, realni život i na sebe preuzimaju odgovornost da svojom žrtvom spriječe put koji čovječanstvo vodi prema propasti (Domenico samospaljivanjem na rimskom trgu usred sekularne gomile prosvjednika, a pjesnik Gorčakov simbolički prenošenjem svijeće preko termalnog izvora a da ne ugasne). Približavanje barem na nekoliko stuba duhovnom savršenstvu Tarkovski suprotstavlja 
sveopćoj duhovnoj degradaciji i podlijeganju cinizmu. I sam je svjestan svojih uzora i ukorijenjenosti u ruskoj tradicij:

"To stanje duše nije strano najboljim tradicijama ruske inteligencije koja je časna, nemirna i suosjećajna i koja grozničavo traži vjeru, ideale i dobrotu. Gorčakov je jedan od njih. Čovjek me zanima po svojoj sposobnosti da služi nečem višem, po svom otporu, ili svojoj nesposobnosti da se povinuje 'običnom' moralu, uskom i bijednom" (Vučinić 2013:10).

Ne treba ni napominjati kako Aleksander, Andrej Gorčakov i Andrej Rubljov (svi umjetnici po pozivu) imaju mnogo i od samoga Tarkovskog i odraz su njegova konzistentnog promišljanja položaja umjetnika i umjetnosti u "pogrešnom svijetu". Poput Sokurova, i filmovi Tarkovskog svojom stilskom strukturom kao da slijede misli ruskog svećenika i filozofa Pavla Florenskog i parafraziraju njegovu koncepciju ikone kao prozora prema onostranom; porozne granice između vidljivog i nevidljivog svijeta. Filmske slike opiru se svakom konačno definiranom, čak i intelektualnom određenju. "lako s jedne strane djeluju krajnje opipljivo, materijalno, one su uvijek i putokaz ka drugom svijetu." (ibid.:14). Već je antropolog Edgar Morin isticao magiju filma odnosno njegovu strukturiranu formu začaravanja koja mora biti sagledana u svojoj antiracionalističkoj prirodi (Morin 2005). Film se uistinu pokazao kao iznimno plodno tlo za mistične, duhovne implikacije (Bergman, Bresson, Dreyer), međutim to je teško zamisliti iz današnje perspektive zabavnoindustrijske mašinerije i njezina sofisticiranijeg rođaka, elitističkog svijeta filmskih festivala.

\section{JURODIVI KAO SINTEZA ELITNE I PUČKE KULTURE}

Na primjeru nekoliko umjetnika analizirali smo utjecaj jednog fenomena koji se smatra tipično ruskim iako je izniknuo na zajedničkom tlu europske narodne kulture.

Burke nas je naučio tomu da ne možemo govoriti o izvornoj narodnoj kulturi u smislu nacionalne isključivosti, nego su različiti fenomeni i duhovna kretanja u Europi umreženi. Kod Burkea narodno je sve što nije elitno, odnosno kultura karakteristična za seljake i obrtnike. To je "neslužbena kultura, kultura neelitnih, podređenih klasa, kao što ih je nazivao Gramsci" (Burke 1991:5). Usprkos romantičarskim zabludama intelektualaca s početka 19. stoljeća Burke pokazuje kako narodna kultura nikad nije bila jednoobrazna ili homogena. Odlikovala ju je iznimna raznolikost, međutim ispod te prividne raznolikosti krije se jedinstvo. I danas kada govorimo o narodnoj kulturi postoje zablude o njezinoj "čistoći", "izvornosti" te se zanemaruje važnost kulturnih i društvenih mijena, a pogotovo interakcije tzv. učene, elitne kulture i narodne kulture. Srodno je mišljenje hrvatskog 
etnologa Žarka Španičeka, čija je definicija pučke pobožnosti poslužila kao jedan od ključnih temelja za ovaj rad:

"S jedne strane ona obuhvaća religijska uvjerenja i postupke svih socijalno nižih slojeva i grupa koji ne sudjeluju u društvenoj moći i bogatstvu, a s druge strane, ona se odnosi na sve neslužbene oblike kršćanskih vjerovanja i kulta u kojima mogu sudjelovati, a često sudjeluju, pripadnici svih pa i viših društvenih slojeva." (Španiček 2002:14).

$\mathrm{U}$ tom svjetlu i fenomen svetih luda (jurodivih) u Rusiji rezultat je dvosmjerne interakcije između učene i narodne kulture, a posebno je zanimljiv način na koji su umjetnici i mislioci rekontekstualizirali fenomen jurodivih kao putokaz za budućnost prema kojoj bi se zemlja trebala kretati (Dostojevski) ili za duboko osobnu filozofiju umjetnosti (Tarkovski). Dostojevski priziva sakralnu ontologiju srednjovjekovlja i njegovo nadmoćno vizualno i slušno imaginarno - to je smisao jurodivosti i njezine estetske dimenzije kako je vide ruski umjetnici.

Burke u svojoj knjizi pokazuje kako je u 17. stoljeću diljem Europe otpočela reforma narodne kulture, tj. sustavni pokušaj nekih obrazovanih slojeva da izmijene stavove i vrijednosti preostalog stanovništva, odnosno da ih poboljšaju (Burke 1991:167). Pritom je ključno njihovo zalaganje za odvajanje svetoga od profanoga. U početnoj fazi oni koji su se smatrali pravovjernima nastojali su razoriti tradicionalnu bliskost sa svetim, jer su mislili da se nepoštivanje vjere razvija upravo zbog prevelike bliskosti (ibid.:170). Etika reformatora zalaže se za ćudoređe, marljivost, razboritost, razum, samosvladavanje, trezvenost i štedljivost. Burke je naziva "malograđanskom etikom" i pokazuje kako je ona u sukobu s tradicionalnom etikom koja nije strogo definirana, ali jače ističe vrijednosti plemenitosti i spontanosti i lakše podnosi nered (ibid.:171). Reformu narodne kulture Burke opisuje kao opći europski pokret usprkos razlikama vjeroispovijesti. lako mnogi povjesničari oklijevaju uključiti i Rusiju i ostaju suzdržani kada se tiče širenja njihovih zaključaka i na pravoslavlje, Burke iste inicijative nalazi i u Rusiji, a usmjerene su protiv pučkog teatra i velike uloge jurodivih u lokalnim svetkovinama. Pritom je ključan glasoviti ruski crkveni sabor koji je održan 1551. godine pod nazivom Stoglav. Ovi pokušaji da se narodna kultura očisti od onog što su reformatori smatrali poganskim elementima ili razuzdanošću, podrazumijeva stvaranje nove narodne kulture ali na tradicionalnim osnovama. Bachova vjerska glazba ima korijene u luteranskoj narodnoj kulturi, Savonarolino slavno spaljivanje taština u Firenci svjesna je zamjena paljenja krijesova i pokladnih kola (ibid.:181, 183). Međutim, u drugoj fazi reformacije raste uloga laika, natprirodno se više uopće ne shvaća ozbiljno. Sva ta vjerovanja smatraju se iracionalnim, pa tako i jurodivi koji su čak i u svoje zlatno doba smatrani graničnim, kontroverznim slučajem i bili problematični zbog svoje ekscentričnosti. Burke piše kako 
je jedna od posljedica reformacijskog pokreta bila širenje jaza između elitne i narodne kulture. "Reformatori nisu namjeravali stvoriti vlastitu zasebnu pročišćenu kulturu, oni su željeli obuhvatiti narod, povući sve za sobom" (ibid.:192). Međutim, dogodilo se upravo suprotno - reforme su mnogo brže i sustavnije djelovale na obrazovane slojeve i tako mnogo jače odvojile manjinu od narodnih tradicija.

Jaz je to koji ruski umjetnici, mislioci poput Dostojevskog i Tarkovskog, nikad nisu prežalili i u njemu su vidjeli fundamentalnu preokupaciju umjetnosti i zadaće umjetnika u povezivanju putem simbola i borbi protiv potiskivanja natprirodnoga, ili, riječima Maxa Webera, "raščaravanja svijeta" (Entzauberung der Welt). Promjena stavova prema medicini, proricanju i čarobnjaštvu najviše ilustrira promjene i način na koji više klase odbacuju narodni pogled na svijet (Küenzlen 2005). Viši se slojevi nisu povukli u jednoj generaciji, nego se taj proces u različitim dijelovima Europe događao u različito vrijeme. Ipak, oko 1800. u većem dijelu Europe "svećenstvo, plemstvo, trgovci, ljudi slobodnih zanimanja i njihove žene prepuštaju narodnu kulturu nižim slojevima" (ibid.:212). Pojam narod (engl. people) više ne znači "svatko", nego "obični puk", a narodna kultura više nije "kultura svih" (druga kultura obrazovanima i jedina kultura svima ostalima). Do uzmaka viših klasa iz narodne kulture u Rusiji dolazi znatno kasnije nego u zemljama zapadne Europe poput Francuske i Engleske. Burke piše: "Sva je prilika da su ruski plemići bili ti koji će posljednji u Europi napustiti narodne tradicije, usprkos nastojanjima Petra Velikoga da ih pozapadnjači." Navodi primjer poznat čitatelju Rata i mira i drugih ruskih romana - plemići su u svojim domaćinstvima držali patuljke i lakrdijaše, a plemkinje su obožavale ikone i jurodive jednako kao i seljaci (ibid.:219). Kod Rusa dakle nije riječ o zapadnjačkom bijegu iz svijeta koji više nije začaran, fascinaciji čudesnim i fantastičnim kao nečemu egzotičnom, nego pobuni protiv desakralizacije društva drukčijeg tipa.

\section{PREMA ZAKLJUČKU}

Za razliku od Velikog Inkvizitora, ${ }^{4}$ jurodivi nije prosvjetitelj, reformator ni revolucionar. On želi razotkriti viši božanski poredak u konkretnim životnim prilikama, a ne učiniti te prilike božanskim, pravednim i istinitim, i odstraniti bol i patnju. Ono što najviše odlikuje jurodive, kao i Španičekove slavonske pučke svece, nisu mistična iskustva i neobične sposobnosti, nego uvjerenost u božanski poziv i autentičnost svoga poslanja (Španiček 2002:272) na kojoj su izgradili moralnu dosljednost i nekonformističku pobožnost. No dok slavonski pučki sveci svojim djelovanjem usprkos ambivalentnog odnosa lokalnog

\footnotetext{
${ }^{4}$ Naslov pripovijesti koju Ivan Karamazov priča Aljoši Karamazovu u romanu F. M. Dostojevskog Braća Karamazovi.
} 
svećenstva prema njima potvrđuju autoritet službene Crkve i njezina naučavanja, jurodivi joj se nerijetko protive i suprotstavljaju. Službena religija nije moguća bez neslužbene religije koju je iznjedrila jer ona omogućuje intimniji doživljaj i iskreniji izraz vjere. Bitne karakteristike pučke pobožnosti jesu da je kolektivna - odražava zajedničke postupke i uvjerenja neke zajednice, a nije new age "duhovnost rađena po mjeri" individue. Njezin je cilj postizanje snažnog osjećaja božje prisutnosti u svakodnevnom životu, odnosno borba protiv desakralizacije koju je otpočela službena religija svojom podjelom na sveto i profano. U tradicijskoj kulturi miješaju se službeno i folklorno, vjersko i magijsko - no jurodivost i srodni oblici nekonformističke duhovnosti teže heterodoksiji.

Poput jurodivih i umjetnici su često percipirani kao da egzistiraju na tankoj granici između ludosti i mudrosti. Zanimljiva je i analogija umjetnosti i šamanizma - naime svaki šaman i umjetnik, prepoznatljiv je po svojem stilu, a primarna polja izražavanja su mu usmena i kazališno-performativna umjetnost (Perrin 2010:66). On crta simbolične likove koji predstavljaju bića s drugog svijeta, a kada pacijent legne na njih, ta radnja nekom vrstom transfera pridonosi njegovu ozdravljenju. Ova terapeutska uloga zajednička je i funkciji ikona kako je opisuje Florenski (Florenski 2001), a koja je utjecala na Tarkovskog i Sokurova. Velike religije pretpostavljaju jaz između dvaju svjetova, u tom smislu jurodivost je bliža šamanizmu jer otklanja taj jaz. Najveći među ruskim umjetnicima pokušavali su "luđački" putem slika i simbola, udahnuti novi duh svijetu. Ne duhovnost po vlastitoj mjeri karakterističnu za new age doba nego kolektivnu, egalitarnu zajednicu duha čiji je jurodivi glasnik, utjelovljenje. ${ }^{5}$ Tarkovski i drugi u potrazi su za mističnim sudjelovanjem između čovjeka i svijeta. Oni osuđuju jaz između svijeta i čovjeka, duha i čula, koji su posljedica vladavine znanosti, monoteizma i mehanicističke organizacije rada i dokolice.

Dostojevski vjeruje kako je bitno znanje nadahnuto znanje - ono koje se dobiva neposredno od nevidljivoga, ključno je otvaranje prema drugom svijetu. Pritom glavnu ulogu igra nadahnuti posrednik (umjetnik, jurodivi). U pitanju je specifično shvaćanje umjetnika kao svete lude koji nastoji doprijeti do puka i sjediniti pučku i učenu, elitnu kulturu - oboje zalaze u mračne predjele duše kako bi donijeli svjetlo. Kada se razbuktaju boje ikona na kraju crno-bijelog, tmurnog, blatnjavog filmskog krajolika Andreja Rubljova, gledatelj doživljava duhovno uzdizanje, iako ne mora biti upoznat sa specifičnim religijskim naslijeđem na kojem Tarkovski gradi svoje filmsko-temporalne skulpture. U sibirskih šamana san se smatra jezikom nevidljivoga, srodno je to načinu na koji Tarkovski i Sokurov vide film, a Florenski ikonu. Sve troje ruskih umjetnika

\footnotetext{
${ }^{5}$ Na sličan način pojedini umjetnici doživljavali su šamana kao arhetipskog umjetnika (još za vrijeme francuskog prosvjetiteljstva vračeve ili iscjelitelje uspoređivalo se sa zapadnim stvaraocima). U tom kontekstu treba spomenuti i njemačkoga performativno-konceptualnog umjetnika Josepha Beuysa i njegovo specifično viđenje šamana-umjetnika kao osobe koja proizvodi simbole i obrede koji na radikalan način odražavaju, često skrivenu, društvenu stvarnost.
} 
umjetnički poziv shvaćaju kao patnju i odgovornost koja zahtijeva veliko samoodricanje, a ne hedonističko izražavanje vlastite kreativnosti. Naglašena religijska misija spasenja prisutna u Dostojevskog, kod Tarkovskog biva transformirana u istančanu osobnu mitologiju s osebujnom i produhovljenom estetikom.

U ovom se radu jurodivost razmatra kao simbolično i ritualno ponašanje, a u njezinim objašnjenjima kulturni razlozi pretežu nad psihološkim ili fiziološkim razlozima. Nameće se zaključak kako je interakcija između visoke i pučke kulture mnogo složenija nego što se čini na prvi pogled, onkraj generalizacija na razini klasa, društvenih etapa i vremenskih epoha ima itekako prostora za proučavanje specifičnog odnosa pojedinaca na razmeđu tzv. visoke i niske kulture prema određenim fenomenima. $\mathrm{Na}$ tragu ikonologije kako ju je osmislio povjesničar umjetnosti Erwin Panofsky trebalo bi se baviti ne samo formom i sadržajem umjetničkih djela, nego dubljom analizom, tj. dijagnostikom stavova i vrijednosti kojih su umjetnička djela simptomi (Panofsky 1972). Antropolozi, etnolozi i stručnjaci iz srodnih disciplina tek počinju odgovarati na pitanja ove vrste. Arhaično viđenje umjetnosti inspirirano jurodivima nekoliko istaknutih ruskih mislioca iz današnje perspektive djeluje neobično i naivno, u svakom slučaju nameću se brojni prigovori zbog mistifikacije. No iza njega stoji žudnja za spoznajom i bivanjem koja nastoji ostati vjerna tradiciji, ali je i nadići. U pitanju je težnja do neslućenih i za naše duhovno osiromašeno doba, nedostižnih visina. Kako nas uči parabola, u ludom svijetu teško je razaznati sveca od luđaka.

\section{LITERATURA}

BAHTIN, Mihail. 1978. Stvaralaštvo Fransoa Rablea i narodna kultura srednjega veka i renesanse. Beograd: Nolit.

BAHTIN, Mihail. 1981. The Dialogic Imagination: Four Essays. Austin: University of Texas Press.

BAHTIN, Mihail. 1984. Problems of Dostoevsky's Poetics. Minneapolis: University of Minnesota Press.

BERDJAJEV, Nikolaj. 1991. Novo srednjovjekovlje: razmišljanje o sudbini Rusije i Evrope. Split: Laus.

BERDJAJEV, Nikolaj. 2006. Ruska ideja. Zagreb: Demetra.

BURKE, Peter. 1991. Junaci, nitkovi i lude: Narodna kultura predindustrijske Evrope. Zagreb: Školska knjiga.

DOUGLAS, Mary. 1966. Purity and Danger: an Analysis of the Concepts of Pollution and Taboo. New York: Routledge.

FLORENSKI, Pavle. 2001. Ikonostas. Nikšić: Jasen. 
FOUCAULT, Michel. 2009. Rađanje klinike: arheologija medicinskog opažanja.

Novi Sad: Mediterran Publishing.

FOUCAULT, Michel. 2013. Istorija ludila u doba klasicizma. Novi Sad: Mediterran Publishing

GOODICH, Michael. 1982. Vita perfecta: The Ideal of Sainthood in the Thirteenth Century.

Stuttgart: Anton Hiersemann.

GUREVIČ, Aron. 1987. Problemi narodne kulture u srednjem veku. Beograd: Grafos.

KORYCKA, Agnieszka Magdalena. 2016. "An attempt to approach the sacred through the film on the example of the analysis and interpretation of the journey of a yurodivy in the film 'The Lonely Voice of Man' by Alexander Sokurov". Adeptus: pismo humanistów, vol. 7. DOI: https://doi.org/10.11649/a.2016.003

KÜENZLEN, Gottfried. 2005. "Max Weber: religija i raščaravanje svijeta". Filozofska istraživanja, vol. 25/3:737-745. https://hrcak.srce.hr/202171

LE GOFF, Jacques. 1973. Srednjovekovna civilizacija zapadne Evrope. Beograd: Izdavački zavod Jugoslavija.

MORIN, Edgar. 2005. The Cinema, or the Imaginary Man. Minneapolis: University of Minnesota Press.

MURAV, Harriet. 1992. Holy Foolishness - Dostoevsky's Novels - The Poetics of Cultural Critique. Stanford: Stanford University Press.

OTTO, Rudolf. 2006. Sveto - o iracionalnom u ideji božanskog i njezinu odnosu spram racionalnoga. Scarabeus-naklada: Zagreb.

PANČENKO, A. M. 1976. "Laughter as Sight". U Laughter in Ancient Russia, ur. D. S. Lihačev i A. M. Pančenko. Lenjingrad: Nauka, 91-183.

PANOFSKY, Erwin. 1972. "Ikonografija i ikonologija: uvod u proučavanje renesansne umjetnosti”. Život umjetnosti: časopis za pitanja likovne kulture, vol. 17:67-79. https://www.ipu.hr/content/zivot-umjetnosti/ZU_17-1972_067-079_Panofsky.pdf PELIKAN, Jaroslav. 2001. Fools for Christ: Essays on the True, the Good, and the Beautiful. Philadelphia: Fortress Press.

PERRIN, Michel. 2002. Šamanizam. Zagreb: Kulturno informativni centar i Naklada Jesenski i Turk.

ŠPANIČEK, Žarko. 2002. Slavonski pučki proroci i sveci. Slavonski Brod: Hrvatski institut za povijest.

TARKOVSKY, Andrey. 1991. Time Within Time. The Diaries 1970-1986. Calcutta: Seagull Books.

TARKOVSKI, Andrej. 1999. Vajanje u vremenu. Beograd: Makart.

THOMPSON, Ewa M. 1987. Understanding Russia: The Holy Fool in Russian Culture. Lanham: University Press of America.

VODOLAZKIN, Jevgenij. 2013. "Sveti luđaci u ruskoj tradiciji". Novosti iz Rusije. Russia Beyond the Headlines, 15. 6. 2013. URL: https://hr.rbth.com/arts/2013/06/15/ sveti_ludaci_u_ruskoj_tradiciji_20033 (pristup 1. 4. 2017.). 
VUČINIĆ. Srđan. 2013. "Andrej Tarkovski - Skica za jednu filozofiju umetnosti”. P.U.L.S.E.

- Magazin za umetnost i kulturu, 2. 8. 2013.

URL: http://ulis.pulse.rs/andrej-tarkovski-skica-za-jednu-filozofiju-umetnosti/ (pristup 1. 4. 2017.).

VUČINIĆ. Srđan. 2015. "Tarkovski i smisao umetnosti". P.U.L.S.E. - Magazin za umetnost $i$ kulturu. URL: http://pulse.rs/tarkovski-i-smisao-umetnosti/ (pristup 1. 4. 2017.).

\section{Artist as Yurodivy: Holy Man or Madman?}

\section{Dina Pokrajac}

This essay deals with the holly fool (yurodivy) phenomenon in the cultural history of Russia providing interpretations of various texts - religious, medical, but primarily artistic ones (literature and film). Russian artists and intellectuals often practise mysticism and for them the sacred is a transcendental ontological reality to be experimented with. The author examines the way in which the yurodivy, an idiosyncrasy of Russian folk culture, at a certain historical moment became entwined with the thought of Russian authors such as Dostoevsky, Berdjajev and Tarkovsky, providing them with a form for a religious conception of art and a specific vision of the artist as a yurodivi "who mocks the world by day, only to mourn it by night" and artistic works as "pathways towards the other world".

Keywords: Andrei Tarkovsky, Fyodor M. Dostoevsky, Alexander Sokurov, Nicolai Berdyaev, holly fool, the Russian idea, heterodoxy, film and literary anthropology, yurodivy

Articles published in this journal are Open Access and can be distributed under the terms and conditions of the Creative Commons license Attribution-NonCommercial-NoDerivatives 4.0 (http://creativecommons.org/licenses/by-nc-nd/4.0/) 